\title{
Splenic B Lymphocyte Programmed Cell Death Is Prevented by Nitric Oxide Release Through Mechanisms Involving Sustained Bcl-2 Levels
}

\author{
Ana M. Genaro, * Sonsoles Hortelano, * Alberto Alvarez, ${ }^{\ddagger}$ Carlos Martínez-A., ${ }^{5}$ and Lisardo Boscá * \\ *Instituto de Bioquímica (Centro Mixto CSIC-UCM) and ${ }^{\ddagger}$ Centro de Citometría de Flujo, Facultad de Farmacia, 28040 Madrid, Spain; \\ and ${ }^{8}$ Centro Nacional de Biotecnología (CSIC), Cantoblanco, 28049 Madrid, Spain
}

\begin{abstract}
Incubation of ex vivo cultured mature $B$ cells in the presence of nitric oxide or nitric oxide-donor substances delays programmed cell death as determined by the appearance of DNA laddering in agarose gel electrophoresis or by flowcytometry analysis of DNA. Nitric oxide also rescues B cells from antigen-induced apoptosis but fails to provide a costimulatory signal that converts the signal elicited by the antigen into a proliferative response. The protective effects of nitric oxide against programmed cell death can be reproduced by treatment of the cells with permeant analogues of cyclic GMP. Regarding the mechanisms by which nitric oxide prevents apoptosis in $B$ cells, we have observed that nitric oxide release prevents the drop in the expression of the protooncogene bcl-2, both at the mRNA and protein levels, suggesting the existence of an unknown pathway that links nitric oxide signaling with Bcl-2 expression. (J. Clin. Invest. 1995. 95:1884-1890.) Key words: nitric oxide • B cells $\bullet$ apoptosis $\bullet$ Bcl-2 $\bullet$ MHC-I
\end{abstract}

\section{Introduction}

Programmed cell death (PCD) ${ }^{1}$ is a process through which individual cells are deleted in the course of development or cell turnover in many tissues $(1,2)$. In the immune system negative selection of the B and T cell lineages is mediated by apoptosis (3-5). Current perspectives implicate growth factors, a wide array of cytokines and hormones, as well as the level of expression of "antiapoptotic" genes, such as $b c l-2, b c l-x$, or bax, as critical factors controlling PCD (6-8).

Isolated mature splenic B cells, in contrast to isolated mature $\mathrm{T}$ cells, rapidly undergo apoptosis in the absence of activation by specific antigens or polyclonal mitogens (3-5). However, in immature B cells, such as the lymphoma WEHI-231 cell line, signaling through the IgM membrane receptor results in cell growth arrest and in the initiation of a series of events characteristic of PCD, therefore suggesting an important role of PCD in

Address correspondence to Lisardo Boscá, Instituto de Bioquímica, Facultad de Farmacia, 28040 Madrid, Spain.

Received for publication 20 June 1994 and in revised form 18 November 1994.

1. Abbreviations used in this paper: cGMP, cyclic GMP; PCD, programmed cell death; PDBu, phorbol 12,13-dibutyrate; SIN-1, 3-morpholinosydnonimine; sMHC-I, soluble MHC-I.

J. Clin. Invest.

(c) The American Society for Clinical Investigation, Inc.

0021-9738/95/04/1884/07 \$2.00

Volume 95, April 1995, 1884-1890 the deletion of autoreactive B cells (9). The same holds true for B cell precursors derived from fetal liver or bone marrow that require the supply of exogenous IL-3 or IL-7 for in vitro growth, and initiate a precocious PCD after depletion of these factors (10). The levels of Bcl-2, a protein encoded by a gene isolated from the break point of translocations between chromosomes 14 and 18 that is highly expressed in various B cell lymphomas (11), have been shown to be important for prevention of apoptosis $(7,12,13)$. Indeed, overexpression of $b c l-2$ in $B$ cells has a protective function against apoptosis (14-16). However, in the case of $\mathrm{T}$ cells from mice carrying a $b c l-2$ transgene, clonal deletion persists despite the expression of high levels of $b c l-2$, suggesting the existence of alternative pathways controlling the switch from proliferation to apoptosis $(17,18)$.

Since little is known about the nature of the intracellular pathways involved in the control of bcl- 2 levels and finally in prevention of $P C D$, we examined the role of nitric oxide as a possible candidate for PCD modulation in ex vivo cultured $B$ cells. A role of nitric oxide has been proposed in physiopathological situations involving activation of the immune system, such as in the graft versus host disease (19) or deletion of activated macrophages (20). Nitric oxide is synthesized by nitric oxide synthase, from which at least three different genes have been identified $(21,22)$. The mechanism of action of nitric oxide involves covalent modification of proteins (ADP ribosylation and S-nitrosylation), as well as the activation of a soluble guanylate cyclase, cyclic GMP (cGMP), as messenger (21-23). Moreover, it has been proposed that nitric oxide may also influence gene expression as reported for the calcium-mediated transcription of early genes in neural cells, opening a new view concerning the biological effects of this messenger (24).

Here we report that the presence of a low but sustained nitric oxide release prevents apoptosis. This prevention appears to be mediated by an increase in intracellular cGMP and leads to the maintenance of significant levels of $b c l-2$ transcription. These results offer new clues for the understanding of PCD and describe an alternative pathway to maintaining B cell survival as well as to linking nitric oxide release to the maintenance of Bcl-2 expression.

\section{Methods}

Chemicals. cGMP assay kit was from Amersham International (Little Chalfont, UK). Agarose was from Pronadisa (Barcelona, Spain). Potassium nitrosylpentachloruthenate was from Molecular Probes Inc. (Eugene, OR). Goat anti-hamster IgG-POD was from CALTAG Laboratories (San Francisco, CA). Chemicals and biochemicals were from Boehringer Mannheim (Mannheim, FRG), Sigma Chemical Co. (St. Louis, MO), or Merck \& Co., Inc. (West Point, PA).

Mice. 10-wk-old BALB/c (H-2 $\left.{ }^{\mathrm{d}}\right)$ or BIO.D2 $\left(\mathrm{H}-2^{\mathrm{d}}\right)$ mice carrying a $\mu / \kappa$ transgene (25) were bred in our colony. Expression of the transgene was evaluated by PCR as described (25).

Preparation of $B$ cells. Spleens from five to eight animals were pooled 
and mechanically disrupted (1-mm metal mesh). The cell suspension was kept in RPMI 1640 medium and filtered through a $10-\mu \mathrm{m}$ nylon mesh. Nonlymphoid cells were removed by centrifugation over a FicollHypaque (Pharmacia, Uppsala, Sweden) discontinuous gradient. After three washes with RPMI 1640 the cells were resuspended in this medium containing $10 \%$ of batch-tested nonstimulatory FCS, $2 \mathrm{mM}$ glutamine, $50 \mu \mathrm{g} / \mathrm{ml}$ antibiotics, and $50 \mu \mathrm{M} \beta$-mercaptoethanol. B cells were prepared after treatment with anti-Thy-1 antibody plus complement (26). To remove adherent cells, the cell suspension was incubated for $30 \mathrm{~min}$ in plastic tissue culture dishes in the same medium. The purity of the B cell population was assessed by immunofluorescence on a FACScan ${ }^{8}$ cytofluorometer (Becton Dickinson and Co., Cockeysville, MD) and resulted in the expression of $>95 \% \mathrm{Ig}^{+}$and $<1 \%$ of Thy-1.2 $2^{+}$cells. The macrophage contamination in these preparations ranged from 1 to $3 \%$ as determined by CD11b staining. When FACS ${ }^{\circledR}$ (Becton Dickinson and Co.) analysis was used, electronic gating of the lymphocyte population was performed and the macrophage contamination was reduced to $<0.1 \%$. Cell viability was estimated according to the propidium iodideexclusion criteria, and was $>95 \%$. B lymphocytes were maintained at $1 \times 10^{6}$ cells $/ \mathrm{ml}$ in the above described RPMI 1640 medium.

NO sources. Nitric oxide was intracellularly generated using NOdonors (27) or caged NO-compounds such as potassium nitrosylpentachloruthenate after ultraviolet irradiation. A nitric oxide solution was prepared in complete medium previously bubbled with helium, and the concentration was spectrophotometrically determined by the changes in absorbance at 401 and $411 \mathrm{~nm}$ of oxyhemoglobin, using an extinction coefficient of $99,580 \mathrm{M}^{-1} \mathrm{~cm}^{-1}(28)$.

Analysis of DNA fragmentation. Internucleosomal DNA fragmentation was analyzed following the procedure of Gonzalo et al. (29) as follows: The cell suspension $(1-2 \mathrm{ml})$ was centrifuged at $200 \mathrm{~g}$ at $4^{\circ} \mathrm{C}$ for $10 \mathrm{~min}$, and the pellet was washed twice with ice-cold PBS. After resuspension in $250 \mu \mathrm{l}$ of PBS, an equal volume of $20 \mathrm{mM}$ EDTA, $0.5 \%$ Triton $\mathrm{X}-100,5 \mathrm{mM}$ Tris- $\mathrm{HCl}, \mathrm{pH} 8.0$, was added. The incubation was followed for $15 \mathrm{~min}$ at $4^{\circ} \mathrm{C}$. Nuclei were removed by centrifugation at $500 \mathrm{~g}$ for $10 \mathrm{~min}$ and the resulting supernatant was centrifuged at $30,000 \mathrm{~g}$ for $15 \mathrm{~min}$. The fragmented DNA present in the soluble fraction was precipitated with $70 \%$ ethanol plus $2 \mathrm{mM} \mathrm{MgSO}_{4}$, and aliquots were treated for $1 \mathrm{~h}$ at $55^{\circ} \mathrm{C}$ with $0.3 \mathrm{mg} / \mathrm{ml}$ of proteinase $\mathrm{K}$. After two extractions with phenol/chloroform, the DNA was resuspended and analyzed in a $2 \%$ agarose gel and stained with $0.5 \mu \mathrm{g} / \mathrm{ml}$ of ethidium bromide.

Flow cytometry analysis of $B$ cells. After incubation with the appropriate ligands, cells were pelleted and resuspended in PBS containing $0.005 \%$ propidium iodide (30). Cells were analyzed in a FACScan flow cytometer (Becton Dickinson and Co.) equipped with a 5-W argon laser, and the forward scatter was plotted against the propidium iodide fluorescence (30). Data are presented using the dot density plot function, and the percentage of cells in the $\mathrm{R} 3$ plus $\mathrm{R} 4$ region is given in the upper right corner of the plot. Sorting of R3 + R4 and R1 regions was done in a FACStar ${ }^{\circledR}$ PLUS flow cytometer (Becton Dickinson and Co.). Cells in panel R2 correspond to death cells that have altered the membrane permeability, and never exceeded more than $20 \%$ of the cell population (30).

Preparation of soluble MHC class I ( $M M H C-I)$. sMHC-I was purified from detergent-solubilized membranes from C57BL/6 lymphocytes (26) as follows: The lymphocytes, a pool of spleen, thymus, and lymph nodes were homogenized in $5 \mathrm{ml}$ of $1 \mathrm{mM} \mathrm{1,4-dithioerythritol,} 0.5 \mathrm{mM}$ PMSF, $120 \mathrm{mM} \mathrm{NaCl}, 0.5 \mathrm{mM}$ EDTA, and $20 \mathrm{mM}$ Hepes, pH 7.4, and centrifuged twice for $10 \mathrm{~min}$ at $3,000 \mathrm{~g}$. The membrane pellet was resuspended in $1 \mathrm{ml}$ of homogenization buffer containing $0.5 \% \mathrm{NP}-40$ and incubated for $30 \mathrm{~min}$ at $4^{\circ} \mathrm{C}$. After centrifugation at $5,000 \mathrm{~g}$ for 20 min, aliquots of the supernatant were filtered through a Sephadex (Sigma Chemical Co.) G-25 (medium) column $(20 \times 0.5 \mathrm{~cm})$ and equilibrated with PBS to remove the detergent, and the emerging protein was purified by affinity chromatography on an anti $\mathrm{H} 2-\mathrm{K}^{\mathrm{k}} \mathrm{mAb}-\mathrm{Sepha}-$ rose (Sigma Chemical Co.) column prepared using $\mathrm{CNBr}$-activated Sepharose and a commercial $\mathrm{H}_{2}-\mathrm{K}^{\mathrm{k}} \mathrm{mAb}$ (PharMingen, San Diego, $\mathrm{CA}$ ). The antigen was eluted with $50 \mathrm{mM}$ glycine ( $\mathrm{pH} \mathrm{3.0)}$ ) and stored at $-80^{\circ} \mathrm{C}$. Syngeneic sMHC-I was prepared from BALB $/ c$ lymphocytes and processed following the same protocol.

RNA analysis. The RNA was extracted by the guanidinium isothiocyanate method (31). RNA ( $5 \mu \mathrm{g}$ ) was denatured at $65^{\circ} \mathrm{C}$ for $15 \mathrm{~min}$ in $5 \%$ formaldehyde, $50 \%$ formamide, and $8 \%$ glycerol and were sizeseparated by electrophoresis in a $0.9 \%$ agarose gel containing $2 \%$ formaldehyde. After transference of the RNA to Nytran membranes (NY 13-N; Schleicher \& Schuell, Inc., Keene, NH) with 10X SSC (10×

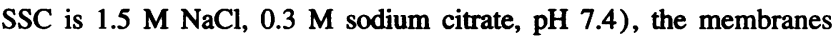
were prehybridized for $6 \mathrm{~h}$ at $42^{\circ} \mathrm{C}$ in $50 \%$ formamide, $0.25 \mathrm{M} \mathrm{NaCl}$, $0.1 \mathrm{M}$ sodium phosphate, $7 \%$ SDS, and $0.01 \%$ of salmon sperm. An 865-bp probe (EcoRI/HindIII fragment) specific for murine bcl-2 was labeled (27\% of efficiency) with $\left[\alpha-{ }^{32} \mathrm{P}\right] \mathrm{dCTP}$ using the Random Primed labeling kit (Boehringer Mannheim). A 500-bp (HindIII/XbaI fragment) of GAPDH was used to normalize the RNA charge of the lanes. The membranes were washed with $0.1 \times$ SSC and $0.1 \%$ SDS at room temperature for $10 \mathrm{~min}$ and twice at $50^{\circ} \mathrm{C}$ for $30 \mathrm{~min}$, and then exposed to X-ray film (X-OMAT, Eastman Kodak Co., Rochester, NY). Quantitation of the films was performed by laser densitometry (Molecular Dynamics, Sunnyvale, CA).

$\mathrm{Bcl}-2$ detection. The amount of Bcl-2 protein was determined using a flow cytometry-based method (7). B cells $\left(5 \times 10^{5}\right)$ were washed twice with PBS and stained with FITC-labeled anti-B220 mAb. After washing twice with PBS, the cells were fixed with PBS containing 4\% paraformaldehyde at $20^{\circ} \mathrm{C}$ for $10 \mathrm{~min}$. After two washes in PBS, the cells were permeabilized with $50 \mu \mathrm{g} / \mathrm{ml}$ of digitonin in PBS for $5 \mathrm{~min}$, the process was stopped by dilution in 0.1 vol of FCS, and the cells were kept at $4^{\circ} \mathrm{C}$. Aliquots $\left(2 \times 10^{5}\right.$ cells $)$ were extensively washed and incubated for $1 \mathrm{~h}$ in PBS with a hamster mAb specific for murine $\mathrm{Bcl}-2$, or a control hamster $\mathrm{mAb}$. The cells were washed and incubated with $\mathrm{F}\left(\mathrm{ab}^{\prime}\right)_{2}$ biotinylated rabbit anti-hamster $\mathrm{IgG}$ for $30 \mathrm{~min}$ at $4^{\circ} \mathrm{C}$ and after staining were analyzed in a FACScan ${ }^{\circledR}$ flow cytometer (Becton Dickinson and Co.). More than $90 \%$ of the cells were permeabilized, as assessed after the staining with propidium iodide. Alternatively, the total levels of Bcl-2 were determined by Western blot analysis using a goat anti-hamster IgG-POD as secondary antibody and revealing the blot following the enhanced chemiluminescence protocol (Amersham).

Determination of cGMP. cGMP was measured in cultures supplemented with $0.5 \mathrm{mM}$ isobutyl-1-methylxanthine to favor the accumulation of this messenger. B cells were stimulated for $2 \mathrm{~h}$, and, after washing with PBS, the cell pellets were resuspended in $0.2 \mathrm{ml}$ of an ice-cold mixture of ethanol:water (2:1, vol:vol). After thorough mixing and centrifugation in an Eppendorf centrifuge (Brinkmann Instruments, Inc., Westbury, NY), samples were speed vacuum-dried and cGMP was measured using a specific binding kit, following the recommendation of the supplier (Amersham).

$\left[{ }^{3} \mathrm{H}\right]$ Thymidine incorporation. Proliferation was determined by culturing $10^{5}$ cells per well in 96 -well plates. $1 \mu \mathrm{Ci}$ of $\left[{ }^{3} \mathrm{H}\right]$ thymidine was added for the last $15-\mathrm{h}$ period of culture (72-h period). The thymidine incorporation was measured by scintillation counting. Results are expressed as the mean disintegrations per minute incorporation of triplicate wells.

\section{Results}

Nitric oxide release delays $P C D$ in $B$ cells. Ex vivo isolated purified splenic B cells, when kept unstimulated, suffered a progressive time-dependent degradation of DNA that was followed by the appearance of a DNA fragmentation pattern observed by agarose gel electrophoresis (Fig. 1 A, - lanes). However, when cells were incubated in the presence of substances that produced a continuous release of nitric oxide (27), such as 3-morpholinosydnonimine (SIN-1), a clear delay in the appearance of the apoptotic ladder pattern was observed (Fig. 1 $A$, + lanes).

Furthermore, an in vivo quantitative analysis of the fraction 
A

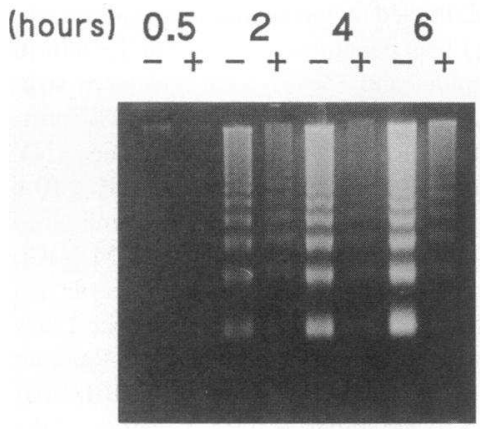

B

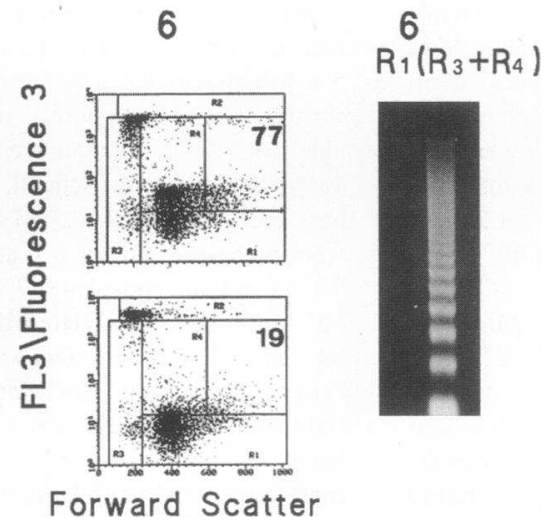

Figure 1. Effect of NO-donors on the apoptosis of ex vivo cultured $B$ cells. $(A)$ Cells $\left(1 \times 10^{6}\right)$ were incubated for the indicated periods of time in the absence ( - lanes) or with $1 \mu \mathrm{M}$ SIN-1 (+ lanes), and the fragmented extranuclear DNA was analyzed by agarose gel electrophoresis. $(B)$ Alternatively, cells were incubated for $6 \mathrm{~h}$ in the absence (upper panel) or in the presence of $1 \mu \mathrm{M}$ SIN-1 (lower panel) and analyzed by flow cytometry. The same number of cells from the nonapoptotic (gate $R 1$ ) and the apoptotic population (gates $R 3+R 4$ ) were sorted. (C) The extranuclear DNA was analyzed by agarose gel electrophoresis. The results show a representative experiment out of three. of cells displaying degradation of DNA was followed by specific changes in the DNA fluorescence when the cells were stained with propidium iodide and analyzed by flow cytometry. As shown in Fig. $1 \mathrm{~B}$, after $6 \mathrm{~h}$ of culture, up to $77 \%$ of the B cells from the untreated population displayed a typical pattern of apoptosis ( $R 3$ plus $R 4$ ) frequency that decreased to $19 \%$ in the presence of SIN-1. To further ensure that the apoptotic B cell population identified by flow cytometry effectively corresponded to cells with internucleosomal DNA fragmentation, the populations discriminated in Fig. $1 B$ were separated by sorting and analyzed by agarose gel electrophoresis (Fig. $1 C$ ). The subpopulation selected in gates $\mathbf{R} 3+\mathbf{R} 4$ is the only one undergoing DNA fragmentation when compared to the $R 1$ population. This protective effect of SIN-1 was also achieved by isosorbide dinitrate, another NO-donor, as well as by repetitive priming of the incubation with a fresh solution of nitric oxide in RPMI 1640-Hepes medium depleted of oxygen (the initial concentration of nitric oxide in this solution was $1 \mu \mathrm{M}$ ). The endogenous NO production in the culture was negligible and below the $\mathrm{nM}$ range after $6 \mathrm{~h}$ of culture. In agreement with the absence of endogenous NO release, the presence of $0.5 \mathrm{mM}$ nitromethylarginine (a nitric oxide synthase inhibitor) in the incubation medium did not alter the apoptotic profile of B cells (not shown). The protective effect of SIN-1 against PCD was dose dependent, and the optimal concentration was $1 \mu \mathrm{M}$ (Table I). As a control, rescue of B cells from PCD by stimulation with either LPS or surface immunoglobulin mAb plus IL-4 decreased the percentage of cells in the R3 + R4 panels (Table I).

Nitric oxide prevents $s M H C$-I-induced apoptosis in B cells. We have recently described a system where $B$ cells expressing a surface immunoglobulin specific for the $\mathrm{H}-2 \mathrm{k}^{\mathbf{k}}$ haplotype of MHC-I, when stimulated with MHC-I alloantigen $\mathrm{H}_{-}-\mathrm{K}^{\mathrm{k}}$, initiate a rapid signaling process that results in apoptosis, an effect that is prevented by some costimulatory signals, among them those involving protein kinase $\mathrm{C}$ activation (26). In the present study we tested the role of NO-donors in this system to validate its protective role against $\mathrm{PCD}$ as a positive costimulatory signal in a model of antigen-induced PCD. As shown in Fig. $2 A$, incubation of B cells for $2 \mathrm{~h}$ with sMHC-I produced an intense DNA laddering that was significantly prevented when SIN-1 was present. Cells treated in this way exhibited a flow cytometric profile reminiscent of that shared by recently isolated B cells (39\% of apoptotic cells in the absence vs $9 \%$ in the presence of SIN-1). As a control in the experiment, incubation of the B cells with low doses of phorbol 12,13-dibutyrate (PDBu; 2 ng/ $\mathrm{ml}$ ) before stimulation with sMHC-I prevented PCD (Fig. 2 $B)$, converting the apoptotic signal into a proliferative response and suggesting the relevance of costimulation (via protein kinase $\mathrm{C}$ in this particular case) on the activation pathway (Table II).

Nitric oxide rescue of $B$ cells from $P C D$ is mediated through an increase in cGMP. Incubation of B cells with several concentrations of a permeant cGMP analogue exhibited a protective effect on the apoptosis detected in recently explanted B cells as well as in B cells stimulated by sMHC-I (Fig. 2 B). Accordingly, to ensure that cGMP was involved in the mechanism of action of nitric oxide in B lymphocytes, experiments were undertaken in which cGMP was measured after stimulation of B cells. As Fig. 3 shows, incubation of B lymphocytes for $2 \mathrm{~h}$ in the presence of SIN-1 produced a 7.2-fold increase in cGMP. The same result was obtained with sodium nitroprusside, a caged NO-releasing compound. As a control, a fresh solution of nitric oxide ( $1 \mu \mathrm{M}$ final concentration) was added to determine the maximal activation of guanylate cyclase in these cells.

Having shown that nitric oxide release in B cells involves

Table I. Flow Cytometry Analysis of Apoptotic B Cells

\begin{tabular}{lcc}
\hline & \multicolumn{2}{c}{ Percentage of apoptotic cells } \\
\cline { 2 - 3 } \multicolumn{1}{c}{ Treatment } & Experiment 1 & Experiment 2 \\
\hline None & 65 & 77 \\
SIN-1 $(0.1 \mu \mathrm{M})$ & 39 & 42 \\
SIN-1 $(1 \mu \mathrm{M})$ & 20 & 19 \\
SIN-1 $(10 \mu \mathrm{M})$ & 19 & 19 \\
SIN-1 $(100 \mu \mathrm{M})$ & 28 & 31 \\
Isosorbide dinitrate $(1 \mu \mathrm{M})$ & 24 & 26 \\
Nitric oxide* $(1 \mu \mathrm{M})$ & 18 & 25 \\
LPS $(25 \mu \mathrm{g} / \mathrm{ml})$ & 17 & 19 \\
sIg-mAb $(5 \mu \mathrm{g} / \mathrm{ml})+\mathrm{IL}-4(2 \mathrm{ng} / \mathrm{ml})$ & 19 & 21 \\
\end{tabular}

B cells were incubated for $6 \mathrm{~h}$ with the indicated ligands, and, after in vivo labeling with propidium iodide, were analyzed by flow cytometry. The percentage of cells in the R3 + R4 gates was determined as representative of the apoptotic population. Results show the values of two different experiments. * A fresh solution of nitric oxide was added to the cell incubation at intervals of $1 \mathrm{~h}$. 


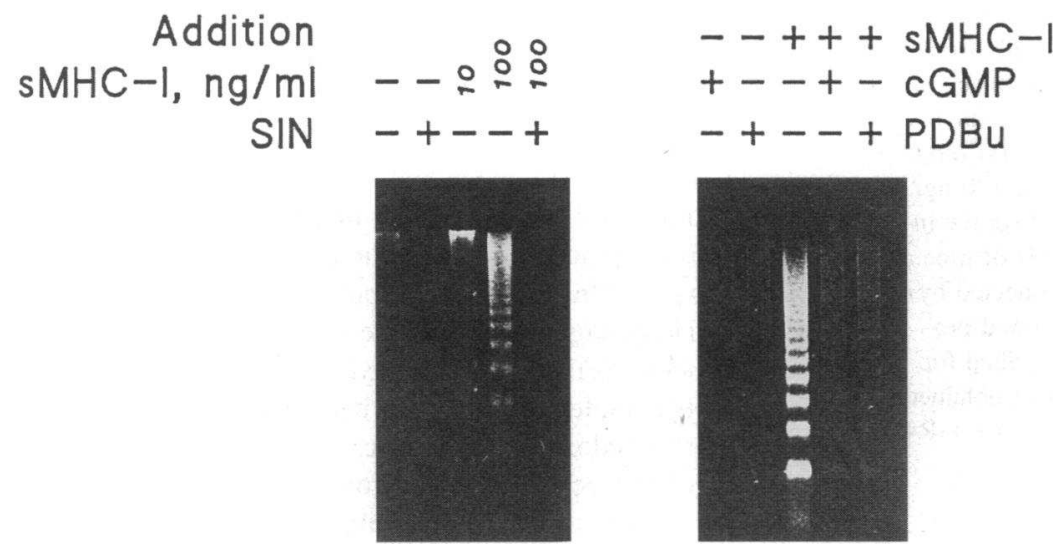

Figure 2. Induction of apoptosis by SMHC-I in B cells from transgenic mice specific for MHC class I is prevented by NO-donors and phorbol esters. B cells from mice carrying a $\mu / \kappa$ transgene were purified as previously described (see Fig. 1). The cells were incubated for $2 \mathrm{~h}$ with $1 \mu \mathrm{M} \mathrm{SIN}-1(A)$, or $100 \mathrm{ng} / \mathrm{ml}$ of purified sMHC-I, $10 \mathrm{nM}$ dibutyryl-cGMP, and $2 \mathrm{ng} /$ $\mathrm{ml} \mathrm{PDBu}(B)$. The figure shows a representative experiment out of three in which the same cell preparation has been incubated with the indicated ligands. the activation of guanylate cyclase, we further determined that cGMP mediated the protective effect of nitric oxide against PCD using flow cytometry. As Fig. 4 shows, incubation of the cells for $4 \mathrm{~h}$ with $10 \mathrm{nM}$ cGMP provoked a decrease in the spontaneous and antigen-induced PCD of B cells from 67 to $21 \%$ and from 32 to $12 \%$, respectively.

A more extensive characterization of the mechanism of action of NO-donors and PDBu in preventing apoptosis was undertaken. While in the short period of time $(<12 \mathrm{~h})$ both agents worked equally well in B cell rescue from PCD, only PDBu was able to costimulate a significant proliferative response upon sMHC-I stimulation (Table II). These results suggested that NO-donors as well as permeant cGMP analogues may require still another cooperative signal to allow the B cells to progress through the cell cycle.

Nitric oxide release sustains bcl-2 levels in B cells. One candidate for prevention of PCD, at least in B cells, is the expression of sustained levels of Bcl-1 (14-16). To study

Table II. Proliferative Response of B Cells Stimulated with Nitric Oxide-donors and Phorbol Esters

\begin{tabular}{lc}
\hline \multicolumn{1}{c}{ Addition } & Disintegrations per minute per well \\
\hline None & $7,968 \pm 673$ \\
sMHC-1 $(100 \mathrm{ng} / \mathrm{ml})$ & $3,494 \pm 345$ \\
+ SIN-1 $(1 \mu \mathrm{M})$ & $1,621 \pm 274$ \\
+ cGMP $(10 \mathrm{nM})$ & $2,956 \pm 318$ \\
+ PDBu $(2 \mathrm{ng} / \mathrm{ml})$ & $18,543 \pm 1,042$ \\
LPS $(25 \mu \mathrm{g} / \mathrm{ml})$ & $171,960 \pm 8,937$ \\
+ SIN-1 $(1 \mu \mathrm{M})$ & $150,603 \pm 10,240$ \\
+ cGMP $(10 \mathrm{nM})$ & $143,826 \pm 11,356$ \\
+ PDBu $(2 \mathrm{ng} / \mathrm{ml})$ & $257,940 \pm 17,627$ \\
\hline
\end{tabular}

Proliferation was determined by culturing purified B cells from $\mu / \kappa$ mice $\left(10^{5}\right.$ cells per well in $96-$ well plates $)$ with the indicated additions. $1 \mu \mathrm{Ci}$ of $\left[{ }^{3} \mathrm{H}\right]$ thymidine was added for the last $18 \mathrm{~h}$ of culture. The thymidine incorporation was measured by scintillation counting after retention over glass fiber filters of the acid-insoluble macromolecular fraction. The maximal proliferative response was obtained at day 3 of culture. A control proliferation with LPS was used to establish the relative efficiency of the different combinations of factors used. Results are expressed as the mean disintegrations per minute \pm SEM incorporation of triplicate wells. whether this situation also applies to B cells incubated with nitric oxide-releasing compounds, we determined the levels of $b c l-2$ mRNA and protein in B cells derived from $\mu / \kappa$ transgenic mice incubated with sMHC-I in the presence of several ligands known to modulate the response to sMHC-I alloantigen. As Fig. 5 shows, exposure of $B$ cells from $\mu / \kappa$ transgenic mice to sMHC-I elicited a drastic drop in the bcl-2 RNA level, an effect that was partially antagonized by SIN-1 and PDBu but not by the inactive phorbol ester $\alpha$-phorboldidecanoate. Indeed, in the presence of SIN-1 (or PDBu), the bcl-2 RNA levels were at least three- to fourfold higher than those from unstimulated cells, reinforcing the view that nitric oxide release was sufficient to maintain the $b c l-2$ RNA levels. Moreover, when the Bcl-2 protein content was measured in situ in permeabilized $\mathrm{B}_{22} \mathrm{O}^{+}$ cells using flow cell cytometry, a clear protective effect of SIN1 was observed over the sMHC-I-induced drop in Bcl-2 (Fig. $6 \mathrm{~A}$ ). Whereas the mean of the fluorescence distribution corresponding to Bcl-2 content decreased from 15 to 7 upon stimulation with SMHC-I, in the presence of SIN-1 the corresponding value was 12. Finally, the total amount of Bcl-2 was also measured by Western blot analysis, and, in agreement with data decribed above, the levels of Bcl-2 were enhanced after addition of SIN-1 or a permeant cGMP analogue (Fig. $6 \mathrm{~B}$ ).

\section{Discussion}

Maturation of B cells from their progenitors in the bone marrow is mainly controlled by cytokines, the temporal pattern of anti-

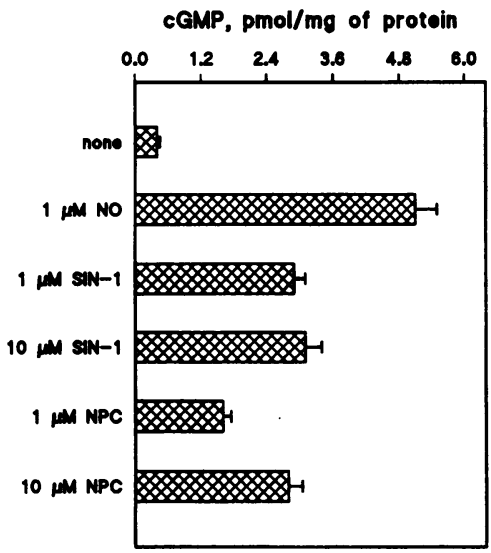

Figure 3. Intracellular cGMP levels in B cells treated with NO-donors. B cells $\left(10^{6}\right)$ were incubated for $2 \mathrm{~h}$ with the indicated concentration of nitric oxide or NO-donors. cGMP was assayed using a commercial kit. Results show the mean \pm SEM of three independent preparations of $B$ cells. 


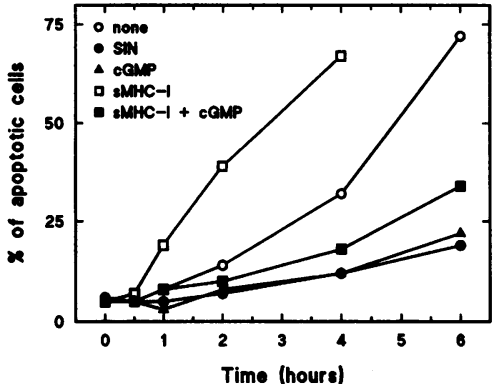

Figure 4. Permeant analogues of cGMP protect against antigen-induced apoptosis. B cells from $\mu / \kappa$ transgenic mice were incubated with 1 $\mu \mathrm{M}$ SIN-1, $10 \mathrm{nM}$ dibutyryl-cGMP, or $100 \mathrm{ng}$ / $\mathrm{ml}$ of sMHC-I for the indicated periods of time. Cells were collected by centrifugation and processed as described for

Fig. $1 B$. Quantitative analysis of the apoptotic population was obtained by flow cytometry determining the percentage of cells in the R3 + R4 panels.

gen recognition, and specific cellular interactions; through all of these, the deletion or functional anergy of the precursor population occurs (32-33). Therefore, the control of the apoptotic process plays a selective role in the course of $B$ cell maturation (32-34).

The identification of the mechanisms involved in B cell survival through the different stages of proliferation and differentiation of the precursors is of interest for the understanding of $B$ cell biology. For this reason, attention has been devoted to the identification of signaling pathways involved in these processes. The protective effect exerted through CD40 signaling in the blockage of the apoptosis in B cells induced after antigen receptor cross-linking is a good example (35). CD40 in humans is expressed in both pre-B cells and mature B cells, and activation through this molecule prevents apoptosis not only in circulating B cells but also in immature B cell lines such as WEHI-231 cells $(34,35)$. CD40 is closely related to the TNF- $\alpha$ receptor, whereas its natural ligand $(\mathrm{CD} 40 \mathrm{~L})$ is structurally related to the family of TNF- $\alpha$ molecules. CD40L is expressed in the cell surface of activated $\mathrm{T}$ cells but not in resting $\mathrm{T}$ cells, therefore providing costimulatory signals in the process of $\mathrm{B}$ cell-T cell interaction $(34,35)$. TNF is an inducer of nitric oxide release in different cell lines, among which are those of lymphoid origin $(36,37)$. We thus considered the possibility that nitric oxide was one of these early molecules (second messengers) that participated in the control of PCD. Nitric oxide is a gaseous molecule released by different cells in response to activation by cytokines (IFN- $\gamma$, TNF- $\alpha$ ), growth factors, and bacterial endotoxins (21, 36-38). Moreover, due to its chemical nature, nitric oxide may easily cross the cell membrane, acting both as an intra- and intercellular messenger, and for this reason it may play a role both in the germinal centers and in the process of recognition of circulating $B$ cells by activated $T$ cells.

The protective role of nitric oxide against PCD in B cells contrasts with the NO-dependent induction of apoptosis observed in other cell types such as macrophages (20), which suggests the existence of cell-specific pathways in the response to nitric oxide. This opposite response to nitric oxide in B cells and macrophages is not unique since neuroprotective and neurodestructive effects of nitric oxide have been reported in neurons; this complex behavior has been explained on the basis of the different redox states of nitric oxide once released in the cytoplasm of the cell $(39,40)$. Moreover, it is also possible that the involvement of other signaling molecules can influence the regulation of the expression of the inducible form of nitric oxide synthase as reported for the complex dual stimulation of macrophages with traces of LPS and IFN- $\gamma(41)$.

Regarding $b c l-2$, recent reports propose that the expression of this protoocogene has a protective role against oxidative stress, involving in neural tissues an increase in the intracellular concentration of glutathione (40). In agreement with these reports, overexpression of $b c l-2$ in neural cell lines prevents PCD by decreasing the generation of reactive oxygen species (40), a situation that does not apply for B cells (42). Our finding that nitric oxide maintains the $b c l-2$ levels both in unstimulated and sMHC-I-activated mature B cells offers a possible explanation for the antiapoptotic effect of nitric oxide in this particular system. Moreover, because Bcl-2 is a long-lived protein under normal conditions, the fall in Bcl-2 content after sMHC-I stimulation indicates that an active Bcl-2 degradation occurs under these conditions, and it suggests the existence of multiple pathways in the control of Bcl-2 degradation. This decrease in Bcl-2 content in cells displaying DNA degradation has been confirmed both by an in situ flow cytometry assay in permeabilized cells and after quantification of the total Bcl-2 content by Western blot analysis.

Expression of $b c l-2$ has been shown to be highly regulated along development of B lymphocytes. For instance, susceptibility to dexamethasone-induced PCD depends on the stage of B cell maturation and correlates well with the amount of $b c l-2$ expressed by individual cells (7). The mechanism by which nitric oxide prevents the drop in $b c l-2$ mRNA levels is yet

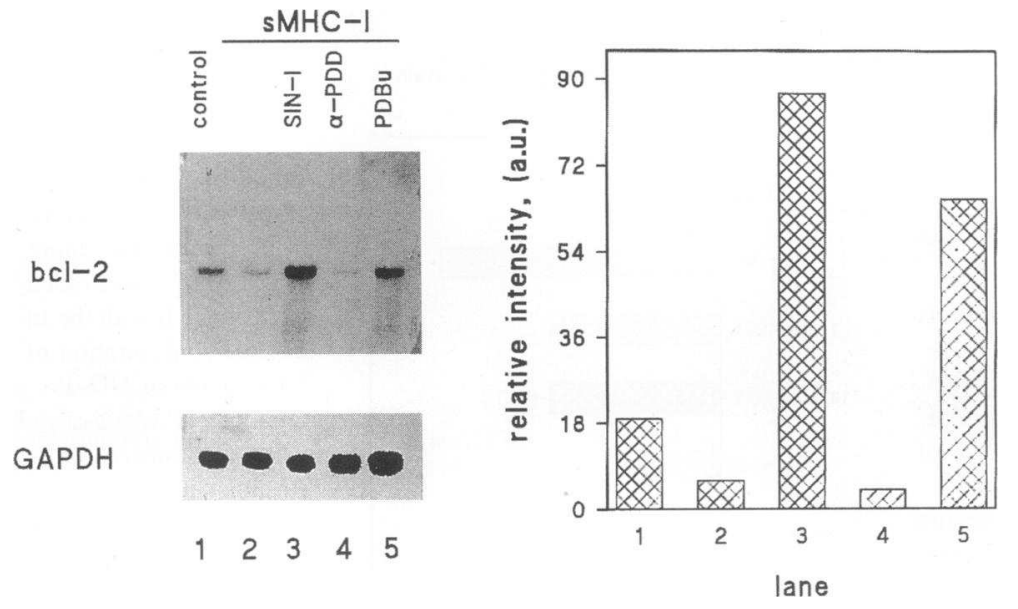

Figure 5. bcl-2 mRNA levels are maintained in splenic B cells incubated with NO-donors. ( $L e f t$ ) B cells from $\mu / \kappa$ transgenic mice were incubated for $6 \mathrm{~h}$ in the absence (lane 1 ) or in the presence of $100 \mathrm{ng} / \mathrm{ml}$ sMHC-I (lanes 2-5), and $1 \mu \mathrm{M}$ SIN-1 (lane 3 ) or $2 \mathrm{ng} / \mathrm{ml}$ of $\alpha$-phorboldidecanoate or $\beta$-PDBu (lanes 4 and 5). (Right) After densitometry, the ratio of intensities corresponding to the $b c l-2$ and GAPDH were expressed in arbitrary units. 


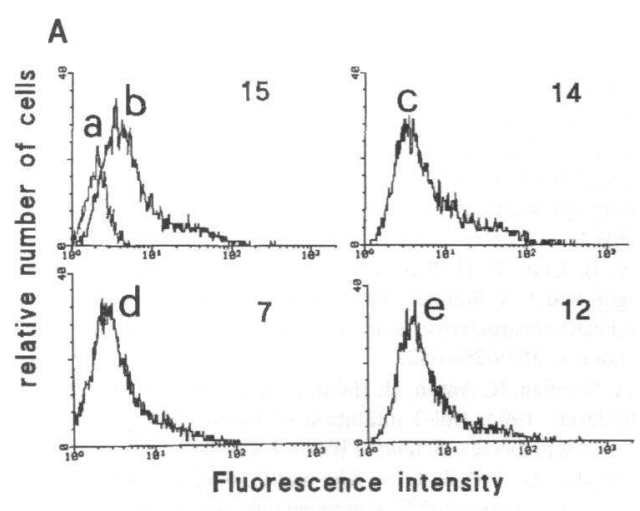

B

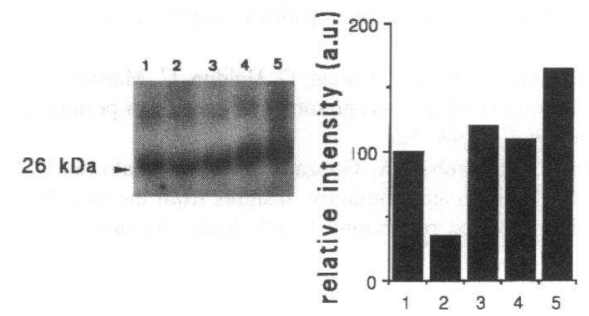

lane

Figure 6. NO-donors maintain Bcl-2 levels in SMHC-I-stimulated cells. (A) B cells from $\mu / \kappa$ transgenic mice were incubated for $6 \mathrm{~h}$ in the absence (traces $a-c$ ) or in the presence of $100 \mathrm{ng} / \mathrm{ml}$ of sMHC-I (traces $d$ and $e$ ) and with $1 \mu \mathrm{M}$ of SIN-1 (traces $c$ and $e$ ). Results show the flow cytometry profile in B220 positive cells for the content in Bcl-2, including a control hamster antibody (trace $a$ ). The mean fluorescence of the distribution is given in the upper quadrant of each plot. The figure shows a representative experiment out of three. $(B)$ Alternatively, total Bcl-2 content ( $10^{7}$ cells) was determined by Western blot analysis in cells incubated for $6 \mathrm{~h}$ in the absence (lane 1) or presence (lanes 24) of $100 \mathrm{ng} / \mathrm{ml}$ of sMHC-I and $1 \mu \mathrm{M} \mathrm{SIN-1}$ (lane 3 ) or $20 \mathrm{nM}$ dibutyryl cGMP (lane 4). Lane 5 corresponds to a control incubated in the presence of $1 \mu \mathrm{M}$ SIN-1. The band intensity was expressed as percentage respect to the content of lane 1 .

unknown, but a few cases in which gene expression is modulated by nitric oxide as occurs in the amplification by nitric oxide of the calcium-dependent transcription of early genes in neuronal cells have been described (24).

The complex regulation of apoptosis and cell survival involves particular combinations of signals leading to pathways that are not always identified. Therefore, it is conceivable that PCD-inhibitory compounds can be used to counteract the increased apoptotic decay of lymphocytes, for instance, triggering after viral infection (43). Moreover, these compounds may exert immunostimulatory effects by impeding the deletion and/or increasing the longevity of stimulated lymphocytes. The results here presented describe a new, useful pathway to prevent apoptosis of B cells, and may provide new insights into the link between the interactions at the membrane surface levels and the distal events that control B cell apoptosis or progression through the division cell cycle and terminal differentiation of B cells (44).

\section{Acknowledgments}

We thank Dr. G. Nuñez for the anti-mouse $b c l-2$ antibody, Dr. Nemazee for the $\mu / \kappa$ (anti-MHC class I, $\mathrm{K}^{\mathrm{k}}$ ) transgenic mice, and E. Lundin for help in the preparation of the manuscript.
This work was supported by grant PM92-070 from Comisión Interministerial de Ciencia y Tecnología, Spain. A. M. Genaro was supported by a postdoctoral fellowship from the Consejo Nacional de Investigaciones Científicas y Técnicas de la República Argentina.

\section{References}

1. Ellis, R. E., J. Y. Yuan, and H. R. Horvitz. 1991. Mechanisms and functions of cell death. Annu. Rev. Cell Biol. 7:663-698.

2. Schwartzman, R. A., and J. A. Cidlowski. 1993. Apoptosis: the biochemistry and molecular biology of programmed cell death. Endocr. Rev. 14:133-151.

3. Duvall, E., and A. H. Wyllie. 1986. Death and the cell. Immunol. Today. 7:115-119.

4. Liu, Y. J., D. E. Joshua, G. T. Williams, C. A. Smith, J. Gordon, and I. C. M. MacLennan. 1989. Mechanism of antigen-driven selection in germinal centers. Nature (Lond.). 342:929-931.

5. Cohen, J. J. 1991. Programmed cell death in the immune system. Adv. Immunol. 50:55-85.

6. Nuñez, G., L. London, D. Hockenbery, M. Alexander, J. P. McKearn, and S. J. Korsmeyer. 1990. Deregulated Bcl-2 gene expression selectively prolongs survival of growth factor-deprived hematopoietic cell lines. J. Immunol. 144:3602-3610.

7. Merino, R., L. Ding, D. J. Veis, S. J. Korsmeyer, and G. Nuñez. 1994. Developmental regulation of the bcl-2 protein and susceptibility to cell death in B lymphocytes. EMBO (Eur. Mol. Biol. Organ.) J. 13:683-689.

8. Oltvai, Z. N., C. L. Milliman, and S. J. Korsmeyer. 1993. Bcl-2 heterodimerizes in vivo with a conserved homolog, Bax, that accelerates programmed cell death. Cell. 74:609-619.

9. Hasbold, J. H., and G. G. B. Klaus. 1990. Anti-immunoglobulin antibodies induce apoptosis in immature cell lymphomas. Eur. J. Immunol. 20:1685-1690.

10. Baixeras, E., G. Kroemer, E. Cuende, C. Márquez, L. Boscá, J. E. AlésMartínez, and C. Martínez-A. 1993. Signal transduction pathways involved in B cell proliferation and apoptosis. Immunol. Rev. 132:5-47.

11. Bakhshi, A., J. P. Jensen, P. Goldman, J. J. Wright, O. W. McBride, A. L. Epstein, and S. J. Korsmeyer. 1985. Cloning the chromosomal breakpoint of $(\mathrm{t} 14 ; 18)$ human lymphomas: clustering around $\mathrm{J}_{\mathrm{H}}$ on chromosome 14 and near a transcriptional unit of 18. Cell. 41:896-899.

12. Veis, D. J., C. M. Sorenson, J. R. Shutter, and S. J. Korsmeyer. 1993. Bcl2-deficient mice demonstrate fulminant lymphoid apoptosis, polycystic kidneys, and hypopigmented hair. Cell. 75:229-240.

13. Boise, L. H., M. Gonzalez-Garcia, C. E. Postema, L. Ding, T. Lindsten, L. A. Turka, X. Mao, G. Nuñez, and C. B. Thompson. 1993. Bcl-x, a bcl-2 related gene that functions as a dominant regulator of apoptotic cell death. Cell. 74:597-608.

14. McDonnell, T. J., N. Deane, F. M. Platt, G. Nuñez, U. Jaeger, J. P. Mckearn, and S. J. Korsmeyer. 1989. Bcl-2-immunoglobulin transgenic mice demonstrate extended B cell survival and follicular lymphoproliferation. Cell. 57:79-88.

15. McDonnell, T. J., G. Nuñez, F. M. Platt, D. Hockenbery, L. London, J. P. Mckearn, and S. J. Korsmeyer. 1990. Deregulated bcl-2-immunoglobulin transgene expands a resting but responsive immunoglobulin-M and immunoglobulin-D-expressing B-cell population. Mol. Cell. Biol. 10:1901-1907.

16. Henderson, S., M. Rowe, C. Gregory, D. Croom-Carter, F. Wang, R. Longnecker, E. Kieff, and A. Rickinson. 1991. Induction of bcl-2 expression by Epstein-Barr virus latent membrane protein 1 protects infected B cells from programmed cell death. Cell. 65:1107-1115.

17. Sentman, C. L., J. R. Shutter, D. Hockenbery, O. Kanagawa, and S. J. Korsmeyer. 1991. Bcl-2 inhibits multiple forms of apoptosis but not negative selection in thymocytes. Cell. 67:879-888.

18. Cuende, E., J. E. Alés-Martinez, L. Ding, M. Gonzalez-García, C. MartínezA., and G. Nuñez. 1993. Programmed cell death by bcl-2-dependent and independent mechanisms in B lymphoma B cells. EMBO (Eur. Mol. Biol. Organ.) J. 12:1555-1560

19. Langrehr, J. M., N. Murase, P. M. Markus, X. Cai, P. Neuhaus, W. Schraut, R. L. Simmons, and R. A. Hoffman. 1992. Nitric oxide production in host-versusgraft and graft-versus-host reactions in the rat. J. Clin. Invest. 90:679-683.

20. Albina, J. E., S. Cui, R. B. Mateo, and J. S. Reichner. 1993. Nitric-oxide mediated apoptosis in murine peritoneal macrophages. J. Immunol. 150:50805085.

21. Lowenstein, C. J., and S. H. Snyder. 1992. Nitric oxide: a novel messenger. Cell. 70:705-707.

22. Moncada, S., R. M. J. Palmer, and E. A. Higgs. 1991. Nitric oxide: physiology, pathophysiology and pharmacology. Pharmacol. Rev. 43:109-142.

23. Marletta, M. A. 1993. Nitric oxide synthase structure and mechanism. $J$. Biol. Chem. 268:12231-12234.

24. Peunova, N., and G. Enikolopov. 1993. Amplification of calcium-induced gene transcription by nitric oxide in neuronal cells. Nature (Lond.). 364:450 453.

25. Nemazee, D. A., and K. Bürki. 1993. Clonal deletion of B lymphocytes in 
a transgenic mouse bearing anti-MHC class I antibody genes. Nature (Lond.). 337:562-566.

26. Genaro, A. M., and L. Boscá. 1993. Early signals in alloantigen induced B-cell proliferation. J. Immunol. 151:1832-1843.

27. Schröder, H., P. Ney, J. Woditsch, and K. Schrör. 1990. Cyclic GMP mediates SIN-1-induced inhibition of human polymorphonuclear leukocytes. Eur. J. Pharmacol. 182:211-218.

28. Knowles, R. G., M. Merrett, M. Salter, and S. Moncada. 1990. Differential induction of brain, lung and liver nitric oxide synthase by endotoxin in the rat. Biochem. J. 270:833-836

29. Gonzalo, J. A., C. Martinez-A., and G. Kroemer. 1992. Expansion and clonal deletion of peripheral $\mathrm{T}$ cells induced by bacterial superantigen is independent of the interleukin-2 pathway. Eur. J. Immunol. 22:1007-1012.

30. Lyons, A. B., K. Samuel, A. Sanderson, and A. H. Maddy. 1992. Simultaneous analysis of immunophenotype and apoptosis of murine thymocytes by single laser flow cytometry. Cytometry. 13:809-814.

31. Chomczymski, P., and N. Sacchi. 1987. Single step method of RNA isolation by acid guanidinium thiocyanate-phenol-chloroform extraction. Anal. Biochem. 162:156-159.

32. Liu, Y.-J., G. D. Johnson, J. Gordon, and I. C. M. MacLennan. 1992. Germinal centres in T-cell-dependent antibody responses. Immunol. Today. 13:17-21.

33. Parker, D. C. 1993. T-cell dependent B cell activation. Annu. Rev. Immunol. 11:331-360

34. Clark, E. A., and J. A. Ledbetter. 1994. How B and T cells talk to each other. Nature (Lond.). 367:425-429.

35. Tsubata, T., J. Wu, and T. Honjo. 1993 B-cell apoptosis induced by antigen receptor crosslinking is blocked by a T-cell signal through CD40. Nature (Lond.). 364:645-648.
36. Nathan, C. 1992. Nitric oxide as a secretory product of mammalian cells. FASEB (Fed. Am. Soc. Exp. Biol.) J. 6:3051-3064.

37. Moncada, S. 1992. The L-arginine: nitric oxide pathway. The 1991 Ulf von Euler Lecture. Acta Physiol. Scand. 145:201-227.

38. Ding, A. H., C. F. Nathan, and D. J. Stuehr. 1988. Release of reactive nitrogen intermediates and reactive oxygen from mouse peritoneal macrophages: comparison of activating cytokines and evidence for independent production. $J$. Immunol. 141:2407-2412.

39. Lipton, S. A., Y. B. Choi, Z. H. Pan, S. Z. Lei, H. S. Chen, N. J. Sucher, J. Loscalzo, D. J. Singel, and J. S. Stamler. 1993. A redox-based mechanism for the neuroprotective and neurodestructive effects of nitric oxide and related nitrosocompounds. Nature (Lond.). 364:626-632.

40. Kane, D. J., T. A. Sarafian, R. Anton, H. Hahn, E. B. Gralla, J. S. Valentine, T. Örd, and D. E. Bredesen. 1993. Bcl-2 inhibition of neural death: decreased generation of reactive oxygen species. Science (Wash. DC). 262:1274-1277.

41. Bogdan, C., Y. Vodovotz, J. Paik, Q-w. Xie, and C. Nathan. 1993. Traces of bacterial lipopolysaccharide suppress IFN- $\gamma$-induced nitric oxide synthase gene expression in primary mouse macrophages. J. Immunol. 151:301-309.

42. Hockenbery, D. M., Z. N. Oltvai, X.-C. Yin, C. L. Milliman, and S. J. Korsmeyer. 1993. Bcl-2 functions in an antioxidant pathway to prevent apoptosis. Cell. 75:241-252.

43. Gonzalo, J. A., G. Gonzalez-García, T. Callan, G. Heldun, C. Martínez-A., and G. Kroemmer. 1994. Linomide inhibits programmed cell death in peripheral T-cells in vivo. Eur. J. Immunol. 24:48-52.

44. Baixeras, E., L. Boscá, C. Stauber, A. Gonzalez, J. A. Gonzalo, and C. Martínez-A. 1994. From apoptosis to autoimmunity. Insights from the signaling pathways leading to proliferation or programmed cell death. Immunol. Rev. 142:53-91. 